This is an open access article under the terms of the CC-BY 3.0 License.

Peer review method: Double-Blind

Date of acceptance: September 30, 2020

Date of publication: November 11, 2020

Original scientific article

DOI: https://www.doi.org/10.47305/JLIA2060014c

\title{
FREEDOM OF EXPRESSION IN TIMES OF COVID-19: CHILLING EFFECT IN HUNGARY AND SERBIA
}

\author{
Kristina Cendic \\ University of Zenica, Faculty of Law, Bosnia and Herzegovina \\ ORCID iD: https://orcid.org/0000-0003-1508-9469 \\ kristina.cendic@gmail.com \\ Gergely Gosztonyi \\ Eötvös Loránd University (ELTE), Faculty of Law, Hungary \\ ORCID iD: https://orcid.org/0000-0002-6551-1536 \\ gosztonyi@ajk.elte.hu
}

\begin{abstract}
New technologies have opened several risks to safety of journalists. More importantly, in the state of emergency caused by the Covid-19 outbreak, journalists and media actors have shifted their activities online more than ever, which also made them more prone to digital threats and attacks. In some regimes there are even organized intimidation campaigns against political opponents causing chilling effect and self-censorship, and jeopardizing freedom of expression in general. Hungary as a member of the European Union since 2004 and Serbia as a leading candidate to join the EU are two countries where the problems and concerns about media freedom is growing every day. The fear from the unknown during the international pandemic gave opportunity to some governments to hide their real political agendas and cover their desire for the 'good-old-fashioned' censorship. The number of countries where some kind of censorship could be found is growing every day. The authors will show two country-casestudies from Hungary and Serbia, where the leaders and the political situations are very similar and could show a (good or bad) example to other countries that would like to follow the illiberal views on media issues.
\end{abstract}

Keywords: Freedom of Expression; Media; Chilling Effect; Covid-19; Hungary; Serbia 


\section{INTRODUCTION}

As the entire world has been struck by a health crisis caused by Covid-19, we have witnessed the rise of the importance of journalism. The role of media encompasses "truthfulness and accuracy of information, good faith or public interest; a sharp difference in the assessment of content from that of opinion, with the latter enjoying greater freedom, and a right to partake in satire and even exaggeration" (CM/Rec (2011)7). Receiving accurate information about the pandemic set an imperative before governments to ensure the rights and safety of media actors when reporting on the most pressing public interest matter of today-the virus. The importance of "free, independent, plural and diverse media have proven to be an indispensable ally of governments and public authorities in informing the public, enabling individuals to exercise their rights to seek and receive information and to develop opinions so that they can take informed decisions and appropriate steps to protect themselves and their communities" and therefore "protecting journalists and media workers must include not only their physical but also their legal and economic safety" (IPI 2020a).

However, during the pandemic, "many governments have deployed laws against disinformation to silence reporters" (Dorroh 2020). According to the Council of Europe (CoE 2020), there are currently 140 alerts in 30 countries, 116 journalists are in detention, while there are 22 cases of impunity for murder. Such "attacks on, and intimidation of, journalists and other media actors inevitably have a very chilling effect on freedom of expression" and "the chill factor is all the more piercing when the prevalence of attacks and intimidation is compounded by a culture of legal impunity for their perpetrators" (McGonagle 2013). Overall, "the Covid-19 pandemic and subsequent governmental measures to contain the spread of the virus have had a roundly negative impact on freedom of expression and journalistic and media freedoms" (McGonagle 2020). Some governments introduced the state of emergency and used the "emergency legislation aimed at tackling the coronavirus to push through restrictions which seriously erode press freedom" (Wiseman 2020). In some countries there were excessive criminal penalties for disinformation, in others such as Hungary and Russia, "the pandemic has been exploited to grab more powers and tighten control over information", whereas in Serbia the government tried "to control reporting, impose restrictions on journalist's access to information, and even try to ban opinion articles" (Wiseman 2020).

This paper will tackle the problems of media landscape and journalistic safety in times of the pandemic, because it seems that pressures on media actors have intensified. However, the worrying fact for these countries is that "while some of the restrictions due to the coronavirus will be temporary, others could be extended long after the health crisis has ended. All, however, are likely to shape the state of media freedom in Europe in the years to come" (Wiseman 2020). 


\section{THEORETICAL FRAMEWORK}

The new media are often said to have "a much more immediate and powerful effect" (McGonagle - Voorhoof 2013), than e.g. print media. There are several indicators in the Recommendation (CM/Rec (2011)7) that aim at clarifying this issue - selfcategorization as a media outlet, membership in professional media organizations, working methods analogue to those typical of media organizations, and, in the new media environment, the capacity and the availability of technical means (e.g. platform or bandwidth) to disseminate content to large audiences online.

The founding document of the Council of Europe is the Convention for the Protection of Human Rights and Fundamental Freedoms, or the European Convention on Human Rights (ECHR), while the implementation of this Convention belongs to the European Court of Human Rights (ECtHR). The crucial article for freedom of expression in this document is Article 10 which in its paragraph 1 states that "Everyone has the right to freedom of expression. This right shall include freedom to hold opinions and to receive and impart information and ideas without interference by public authority and regardless of frontiers." On the other hand, paragraph 2 explains the restrictions that may be imposed on freedom of expression in certain circumstances.

Subject to paragraph 2 of Article 10, it is applicable not only to 'information' or 'ideas' that are favorably received or regarded as inoffensive or as a matter of indifference, but also to those that offend, shock or disturb the State or any sector of the population. Such are the demands of that pluralism, tolerance and broadmindedness without which there is no 'democratic society'. This means, amongst other things that every 'formality', 'condition', 'restriction' or 'penalty' imposed in this sphere must be proportionate to the legitimate aim pursued. ${ }^{1}$ Article 10 applies not only to the content of information but also to the means of dissemination, since any restriction imposed on the latter necessarily interferes with the right to receive and impart information ${ }^{2}$. It is important to note that the limitations of freedom of expression in line with Article 10 of the ECHR are to be applied restrictively. Moreover, when dealing with expressions of public interest, the Court assesses, among other, whether the article(s) in question referred to the matters of public interest, and finally whether there were facts of value judgments and if there were value judgments if they contained enough factual basis.

After domestic legal remedies are exhausted, the injured parties turn to the ECtHR to deal with their human rights being violated, and so in the case of the violation of the right to freedom of expression. The Court deals with actions taken by national authorities in freedom of expression on matters of public interest, and insists on the

\footnotetext{
${ }^{1}$ Handyside v. The United Kingdom (5493/72), 07 December 1976

${ }^{2}$ Autronic AG v. Switzerland (12726/87), 22 May 1990
} 
positive obligations for countries in terms of ensuring freedom of expression. Therefore, even though the legislations differ among European countries, the umbrella principle of Article 10 is evoked when it comes to both countries with a long democratic tradition and in newly established democracies, but with a note that "the practical and effective impact of Article 10 still differs from one member state to another", too (Voorhoof 2014).

The European Court on several occasions provided a greater protection for the statements referring to issues of public interest. The Court concluded that some statements may had been harsh and that they were partially untrue but that it was important to determine "whether in one specific case journalists acted in good faith with a goal to provide public with correct and reliable information in accordance with the code of ethics of journalists". ${ }^{3}$ The concept of correct and reliable information also came into question here, because the Court mentioned that "journalists cannot be asked to verify the information to the same level as other persons, because in this way they would most often not be able to do their job well," but they still must "make big efforts and to be professional when establishing the facts relevant for a disputable statement" (Srdić 2012). One of the cases dealing with matters of public interest was the one of Thorgeir Thorgeirson v. Iceland. ${ }^{4}$ In this case, the newspapers published two articles referring to the brutality of police. In this case, the European Court decided that "whilst the press must not overstep the bounds set, it is nevertheless incumbent on it to impart information and ideas on matters of public interest. Not only does it have the task of imparting such information and ideas: the public also has a right to receive them". ${ }^{5}$ This role has turned out to be particularly important with the Covid-19 outbreak which "brought a wave of measures threatening access to information and media freedom," which is why there is "the need for robust protection for journalists, the media and other actors to enable them to carry out their public watchdog tasks and to produce quality, independent and critical journalism" (McGonagle 2020).

\section{Restrictions in the State of Emergency}

In March 2020, due to the outbreak of Covid-19 which has infected over a million of people and caused thousands not to recover all around the world, many countries declared a state of emergency - a measure which sounds alarming as it is. The very concept of the state of emergency or the public emergency is defined by the Venice Commission. It is stated that such situations involve both derogations from normal human rights standards and alterations in the distribution of functions and powers among the different organs of the State (CDL-STD(1995) 012). It also clearly noted that

\footnotetext{
${ }^{3}$ Tromsø and Stensaas vs. Norway (21980/93), 20 May 1999

${ }^{4}$ Thorgeir Thorgeirson v. Iceland (13778/88), 25 June 1992

${ }^{5}$ Lingens v. Austria (9815/82), 8 July 1986
} 
derogations from fundamental human rights are an especially crucial problem since experience has shown that the gravest violations of human rights tend to occur in the context of states of emergency (CDL-STD(1995) 012). Human rights instruments also involve provisions referring to the state of emergency and so the ECHR in Article 15 allows derogation from fundamental rights in cases of "war or other public emergency threatening the life of the nation". But even in these times of public emergencies, numerous expert organizations urged the countries to carefully assess the restrictions that may be placed on human rights. European Digital Rights Organization asserted that some of the actions taken by governments under exceptional circumstances today can have significant repercussions on freedom of expression, privacy and other human rights both today and tomorrow (EDRI 2020)

\section{HUNGARY}

For so many years in the past, Hungary was seen by many as some kind of eminent pupil in the classroom as it was one of the few ex-communists countries that were widely celebrated for its reforms towards a Western-style political and economical model. To be able to join the European Union in 2004 (15 years after the change of the communist regime), the country had to meet the so-called Copenhagen criteria which are the followings:

- stability of institutions guaranteeing democracy, the rule of law, human rights and respect for and protection of minorities;

- a functioning market economy and the ability to cope with competitive pressure and market forces within the EU;

- ability to take on the obligations of membership, including the capacity to effectively implement the rules, standards and policies that make up the body of EU law (the 'acquis'), and adherence to the aims of political, economic and monetary union (Marktler 2016).

The media field and the regulation related to media are included in the first criterion. After the successful negotiation and amendments to the Hungarian media legislation (Act I of 1996 on Radio and Television), the hurray-optimism of the country lasted for some years (Bajomi-Lázár 2003). There were some bad signs in the first decade of the new century as the country started to be extremely divided into the rightsided and the left-sided part ${ }^{6}$, but the critical point turned out to be the elections of 2010. Fidesz-MPP won the election with a two-thirds majority and started reforms in

\footnotetext{
${ }^{6}$ Viktor Orbán, who was then the president of the biggest opposition party, Fidesz-MPP, suggested several times around 2004 already that instead of the one MTV (Magyar Televizió, Hungarian Television), the public service broadcaster (PSB), and two would be needed: one to be controlled by the government and one to be controlled by the oppositions. He suggested that based on German ARD-ZDF "examples". (MTI 2003)
} 
almost all important fields. One of those reform-projects was related to media. "The controversial media laws passed in autumn 2010 received extensive domestic and international attention", as Gábor Polyák wrote in his article (Polyák 2015). Those two laws (Law CIV of 2010 on the Freedom of the Press and the Fundamental Rules on Media Content, and Law CLXXXV of 2010 on Media Services and Mass Media) created more problems than they solved (Mérték Média Monitor 2012) - although many agreed at that time that some amendments were necessary with the previous media legislation (in defence of the new media legislation: Koltay 2013). Although Audiovisual Media Services Directive, Charter of Fundamental Rights of the European Union and some part of the E-Commerce Directive should be considered in the media field, one has to observe that those heated European debates around the Hungarian Media Law were without a real legal authority as media legislation is mostly not part of the common EU legislation. That means that countries are left alone with their own questions and problems.

Still, nobody expected that the whole media system would be reshaped in a manner it turned out to be. Many say that the Hungarian public service broadcaster became almost a state media again, that right-sided, government-friendly oligarchs turned up and bought several media outlets, that the advertising money of the state itself and state-owned companies are distributed in a specific manner and as one of the most fearful happening, more and more believe that the National Media and Info communications Authority of the country was colonized by the leading political party. And if that is not enough for some alarms to ring, the biggest Hungarian newspaper was bought in dubious circumstances and was suspended than was closed by an Austrian businessman with no previous involvement in the Hungarian media market who soon turned out to be only a henchman of some right-sided media oligarchs wanted to stay in the dark (Fabók - Pethö - Szabó 2016). The same happened with the second biggest online newspaper, origo.hu (Átlátszó.hu 2015). And not only these two fell down. HírTV was one of them also. And more and more print and online newspapers changed their owners. On 12 September 2018 in Strasbourg, the European Parliament adopted a resolution (2017/2131(INL)) stating that the European Council should determine the existence of a clear risk of a serious breach by Hungary of the values on which the Union. Amongst those values, freedom of expression (FoE) is a crucial one and sections 27-32 of the report enumerate some serious infringements ${ }^{7}$.

As a marker for the chilling effects on the Hungarian media field and the daily work of Hungarian journalists, it worth to examine the following: "In the 2013 survey, half the journalists felt that political pressure was so immense that it limited the degree to which the principles of press freedom prevail in their work, while a mere $1 \%$ indicated

\footnotetext{
${ }^{7}$ The reply of the Hungarian government was pretty simple on the official website of the Prime Minister: "The Prime Minister called the so-called Sargentini-report a Soros report, adding that Green Party rapporteur Judith Sargentini, who prepared the report, is one of George Soros's people" (Cabinet Office of the Prime Minister2018).
} 
that he or she felt no pressure at all. Every third journalist claimed that pressure from economic players alone was massive enough to constrain press freedom. Some $60 \%$ of journalists and $67 \%$ of editors stated that they had personally experienced political pressure in the year prior to the survey" (Navratil 2015). Any of those numbers are way higher than a normal system should work with. Besides that, the Hungarian media outlets should live with uncertainty about the exact terms of the media laws' provisions, serious sanctions and the fear of license withdrawal ${ }^{8}$ and true unpredictability (which, as we know from the case-law of the European Court of Human Rights, could cause a serious chilling effect (Erdősi - Gosztonyi - Gyetván - Kiss - Mező - Sziládi - Tatár 2020).

Then the almost unexpected happened in Hungary in December 2018. Almost all pro-government media service providers (websites, newspapers, television channels and radio stations) were, offered by their owners to the newly-formed (August 2018) nonprofit Central European Press and Media Foundation. The financial reasoning is simple here; they 'donated' their 60 billion HUF yearly overall income (184,400,000 EUR) with at least 8 billion HUF yearly overall profits $(24,600,000$ EUR) free of charge to a newlycreated conglomerate. "Obviously, it wasn't philanthropy" claimed the Editorial Board in the New York Times in 2018 (The Editorial Board 2018). Neither the Hungarian Competition Authority nor the National Media and Communications Authority found a legal ground to examine the strange circumstances because the Hungarian government issued the 229/2018 (XII. 5.) Government Decree stating that the Central European Press and Media Foundation "have national strategic importance". And the reasoning for it was one single legal term: because it is the 'public interest'.

We could see that the Hungarian media faced 2020 and the Covid-19 pandemic in a weakened state (and with a stronger State if anybody would like to make jokes in this case). The country took $89^{\text {th }}$ place in the 2020 World Press Freedom Index, which amongst others - stated that "access to information is more and more difficult for independent journalists. They are banned from freely ask politicians in the Parliament or from attending different events. Government politicians do not give interviews to government-critical media outlets" (RSF 2020a). Freedom House's 2020 report (FH 2020) gave Hungary 70/100 on the Global Freedom Score (Partly Free) and 72/100 on the Internet Freedom Score (Free).

The Media Freedom Rapid Response project (co-funded by the European Commission) tracks, monitors and responds to violations of press and media freedom in EU Member States and Candidate Countries. In their first report of four-month (MFRR

\footnotetext{
${ }^{8}$ This happened with two well-established radio stations in the recent-past: the biggest Hungarian community radio, Civil Radio's license was not renewed in October 2019 after 27 years of broadcasting because of some minor infringements (https://amarceurope.eu/civil-radio-wont-stay-silent/) and the same happened with Klubradio in September 2020. The National Media and Info-communications Authority stated that Klubradio "has repeatedly violated the provisions of the Media Act." However, Klubradio said that these statements do not correspond to reality and they are "looking for legal and other means to ensure that Hungary's last independent radio station is not muted" (Kaszás 2020).
} 
2020) four key issued were identified in Hungary. Those threats couldn't be understood without the above snapshots, without understanding the context and how the whole Hungarian media system was weakened into an almost state-dependent situation. The four issues in the report were the followings:

- New criminal legislation against the spreading of "false" or "distorted" information, passed during the state of emergency, caused uncertainty and selfcensorship among media outlets and actors (IPI 2020b);

- Independent media outlets in Hungary already face a precarious financial situation (Wiseman 2020 and IPI 2020c), a result not only of the lockdown but also of years of state-led market manipulation;

- The Covid-19 pandemic has also given cover for attacks against journalists, media workers and press cartoonists;

- On 25 June the Constitutional Court ruled (HCC 2020) that the above-mentioned government decree which prevented the Hungarian Competition Authority from examining the legality of the merger of over $\mathbf{4 7 0}$ media outlets that created the pro-government media conglomerate, Central European Press and Media Foundation was legal.

More and more observers raise their concerns and voice because it seems that the Hungarian government would like to pursue tighter information control and intensify its now decade-long campaign to discredit and undermine critical journalism. The last effort of it was one of the most serious. "Index.hu, the biggest Hungarian website was accounted for nearly half of all page views among independent media in the country" (Bede 2020). In the last week of July, the editor-in-chief of the newspaper was fired by the company's CEO. It was said that this was because of some leaks from the editor-in-chief, but in the background, the dark clouds already gathered around the site for many years. As a result of the loss of their leader, almost 80 journalists, the entire editorial team has left the company and it was a clear sign of some political connections in the backdoor. And same as in the recent attacks against independent media, some right-sided businessman showed up again. The future is very dark and very unclear again.

\section{SERBIA}

According to Reporters without Borders report Serbia is unsafe for journalists (RSF 2020b). Journalists and media actors often face threats and their attackers use fake accounts, bot armies, software and other tools to intimidate them and threaten them. According to the findings of SHARE Foundation's monitoring of digital rights and freedoms (SHARE 2020), in Serbia, threats to journalists are often connected with hate speech, political persecution, intimidation campaigns and persecution of journalists in 
the online sphere. Moreover, there are also reports of the current administration in Serbia suffocating critical journalism at the same time "ensuring that the outlets with the widest reach support the government and smear its perceived opponents" (Bjelotomic, 2020a). According to Željko Bodrožić, president of the Association of Independent Journalists of Serbia (NUNS), the state of emergency introduced due to pandemic made the state of the 'traitors' media much worse, and it "has exposed the government's intention to silence the media that are not under its control and to prevent independent journalists from doing their work"(Janjić 2020).

According to Der Spiegel, the authorities in Serbia have "used the state of emergency and the pandemic to strengthen their executive power and massively restrict freedoms" (Bjelotomic, 2020b). Immediately after the state of emergency was introduced and almost all aspects of Serbian society, much like in other countries, shifted to online sphere, attacks on those spreading (dis)information began. The Government tried to centralize information distributed to the public and forbade anyone not in its Crisis Staff lead by the Prime Minister, from making any statements about the virus. More specifically, no one outside the Crisis Staff was allowed to spread information, whereas those who did could be held accountable under "regulations covering accountability and legal consequences for spreading disinformation during the state of emergency" (EWB 2020). Such decision affected journalists to a great extent and throughout the state of emergency they faced numerous difficulties in performing their role of a public watchdog. A journalist was threatened after the press conference of the Crisis Board, the journalists working for the Center for Investigative Reporting in Serbia received insults from one editor of a magazine on Twitter (SHARE 2020). The magazine in question also published an article speaking about the journalists of the Center in an offensive manner (SHARE 2020), titled: 'How sick are you?'. Radio Valjevo insulted a local doctor and accused her of 'crime' mentioning her alleged connections with an editor of a website from the city of Valjevo (SHARE 2020). A member of the Local Board of the ruling party in the city of Sabac filed charges against a journalist for spreading fake news and causing panic (SHARE 2020). According to Jovana Gligorijevic, a journalist with the weekly political magazine Vreme says she is a frequent target of the ruling party bots whenever she uses mentions the president's name, or the name of the ruling party (Nikolic - Jeremic 2020).

But the most serious case of occurred on April 1 when a journalist Ana Lalic was arrested and ordered a 48-hour detention (Index on censorship 2020a and RSF 2020c). Her article titled 'Clinical Centre of Vojvodina at the breaking point: No protection for nurses', spoke about the lack of equipment for protection such as masks and gloves at the Clinical Center of Vojvodina, relying on the statements of two doctors and one nurse. More specifically, "on Saturday night, nurses working at the so-called Corona Center rebelled and refused to enter patients' rooms because there was no protective equipment. After a few hours, a small amount arrived" (EWB 2020), an anonymous 
doctor told Lalic. The article stated that employees of the Emergency Center and KCV intensive care unit, including those in operating rooms, are entitled to only one protective mask per day (EWB 2020). The sources of the story used their anonymity because "employees (of the center) were forbidden to speak to any media" (Mong 2020). As a result of her article, the hospital reported Lalic to Vojvodina police station and filed a complaint against her for damaging their reputation and upsetting the public (Article-19, 2020). The Clinical center expressed their "outrage over the inaccurate, unverified and malicious" reporting by Nova.rs about the operation of the institution and stated that it "informed the prosecution and the police about it" for disturbing the public and damaging its reputation (EWB 2020). The report was published at about 3 p.m. on Nova.rs and that very evening six police officers came to Ana's apartment, confiscated her laptop and two phones and searched her house, after which she was arrested and taken to custody.

Numerous European Union bodies and journalists' groups reacted on her detention, there was a big "pressure and numerous reactions from journalists, the EU commissioner" (Mong 2020). Article-19 also called for the investigation against Lalic to be dropped and the withdrawal of new regulations that limit the distribution of information on the pandemic to come only from the Prime Minister's office and other selected authorized bodies in Serbia (Article-19, 2020). The Independent Journalists' Association of Vojvodina asked for her to be released immediately, and stated that the police and prosecutors did not react when "state officials threatened the population and journalists in a panic nor when the Crisis Staff sent out text messages saying that a Spanish or Italian scenario is looming but consider reports on whether medical staff is in danger to be a crime" (EWB 2020). The next day she was taken to court, and after two rounds of hearing, she was released after all (Article-19, 2020). Finally, the authorities dropped the charges against Lalic on April 27 (Mong 2020). However, no apologies came from the authorities and there were still many officials who claimed that she was a liar. According to Ana Lalic "the government of Serbia today is fighting on two fronts. One is against virus, and the other is against the true and free press" (Article-19, 2020). Since then, Ana Lalic has been called a victim of 'democracy' in Serbia and received the Deutche Welle Award for freedom of speech (Smajić 2020).

This case raised many questions and showed the lingering problems even more clearly. Namely, some states may take excessive measures fight the pandemic and "curb press freedom and open the door to arbitrary prosecutions, while critical journalists are already harassed by smear campaigns conducted by politicians and other actors amidst the coronavirus crisis" (RSF 2020c). The media landscape in Serbia showed all of its flaws in this case. While the international associations and institutions, local associations of journalists and the few independent media outlets insisted on the release of Ana Lalic, defending journalistic profession and the right to freedom of expression, the progovernment media began a smear campaign against Ana. Even a paid advert appeared 
regularly online with her along with a caption accusing her of acting against the "interests of the state" and calling her "state enemy number 1" (Milovanovic 2020). She has also received numerous serious threats on social media and has faced persistent calls in pro-government media for authorities to prosecute her, making her fear for her personal safety. However, such smear campaigns are unacceptable in a democratic society and they often happen when journalists write about a sensitive topic (Milovanović 2020). In one of the pro-government media, Kurir, Ana Lalic has been labeled as a liar and there have been several texts accusing Ana Lalic of violating the journalistic code - "Ana Lalic was aware she was lying: she violated the press code to bring fear among people" (Kurir 2020a), "An irresponsible journalist Ana Lalic has been released" (Kurir 2020a), "Experts condemn irresponsible behavior of Ana Lalic: Dr Kisic such reporting disturbs us while we are trying to save lives" (Kurir 2020b), "Kurir finds out: journalist Ana Lalic who published false information got her devices back" (Kurir 2020c).

Therefore, in the state of emergency, the polarization of media to 'friendly' and 'unfriendly' has become even clearer because "we have witnessed the attempt by the government to formally introduce censorship; a journalist was recently arrested, while all non-aligned journalists are openly labeled as enemies of the Serbian state and people." (Janjić 2020). Moreover, it seems that "the government targets independent journalists, as they are the only ones who raise uncomfortable questions, that is, questions on subjects of public interest that should be brought to the attention of the public"(Kurir 2020c). Some journalists in Serbia thus found themselves under attacks coming both from public officials as well as other actors they criticize, while trying to fulfill their roles of public watchdogs in risky conditions (RSF 2020c). In times of the pandemic, the "excessive government control, democratic backsliding built on the pre-existing trend of media capture and shrinking of space for media freedoms" (EWB 2020) seem to have become even more prominent in Serbia. Finally, media landscape illustrated the politically divided society in Serbia more than before, because "there are progovernment media which occupy the largest information space and independent media with much less space" (RSF 2020c).

\section{CONCLUSION}

On 14 May 2020 'Index on censorship' published a report stating that "as we mark 50 days since we first started collating attacks on media freedom related to the coronavirus crisis, we're horrified by the number of attacks we have mapped - over 150 in what is ultimately a short period of time" (Index on censorship 2020b). Any kind of crisis help the attacks on Freedom of Expression and fundamental human rights - we all know that. But the number and the allocation are alarming: Russia, Turkey, Hungary, and Serbia are amongst those countries that we are waiting to show up reports like that. 
The so-called "illiberal democracies" (Plattner 2019) are struggling to cope with those rights. But there are reports from countries like United Kingdom, Germany or Spain and this should warn everybody. David Kaye, United Nations Special Rapporteur on the promotion and protection of the right to freedom of opinion and expression, in his latest (July 2020) report (Kaye 2020) called governments around the world to take action to protect and promote freedom of expression during the Covid-19 pandemic, which many states have exploited to crack down on journalism and silence criticism. The Special Rapporteur urged governments to address the challenges we all are facing, amongst them the most important are: "reinforce access to information and share as much as possible; end the practice of internet shutdowns and other limitations on access to the internet and refrain from all attacks on the media and release all journalists detained, whether during or before the pandemic, especially given the health risks they face" (Kaye 2020).

So close to the Covid-19 pandemic, we don't have answers yet if these above described attacks in these illiberal democracies were connected only with the virus or the virus only hide something bigger. We have to watch carefully, because freedom of expression seems to be very fragile in this part of the world at the moment. 


\section{REFERENCES}

1. Article-19, 2020: Serbia: Journalist Ana Lalic arrested for reporting on inadequate hospital facilities for coronavirus. https://www.article19.org/resources/serbiajournalist-ana-lalic-arrested-for-reporting-on-inadequate-hospital-facilities-forcoronavirus/

2. Átlátszó.hu, 2015: The fall of popular independent online news portal, Origo.hu. https://english.atlatszo.hu/2015/03/24/the-fall-of-popular-independent-onlinenews-portal-origo-hu/

3. Bajomi-Lázár, Péter, 2003: Freedom of the Media in Hungary, 1990-2002. PhD diss., Central European University.

4. Bede, Márton (2020, Aug 11): With Index gone, the future looks even bleaker for Hungarian media: https://ipi.media/with-index-gone-the-future-looks-evenbleaker-for-hungarian-media/

5. Bjelotomic, Seneza, 2020a: Serbia falls three places on the Reporters Sans Frontières media freedom list: https://Www.serbianmonitor.com/en/serbia-fallsthree-places-on-the-reporters-sans-frontieres-media-freedom-list/

6. Bjelotomic, Snezana, 2020b: Der Spiegel: "The Serbian authorities have done everything possible to restrict rights and freedoms". https://www.serbianmonitor.com/en/der-spiegel-the-serbian-authorities-havedone-everything-possible-to-restrict-rights-and-freedoms/

7. Cabinet Office of the Prime Minister (2018, June 25): The Sargentini report is a Soros report, http://www.miniszterelnok.hu/the-sargentini-report-is-a-sorosreport/

8. CDL-STD(1995) 012, Venice Commission on Emergency powers

9. $\mathrm{CM} / \operatorname{Rec}(2011) 7$ : Recommendation of the Committee of Ministers to member states on a new notion of media

10. Council of Europe, CoE, 2020: Platform to promote the protection of journalism and safety of journalists. https://www.coe.int/en/web/media-freedom/home

11. Dorroh, Jennifer (2020, June 18): Journalism \& the Pandemic: Threats to Media Freedom \& Safety During Covid-19, International Center for Journalists:

https://www.icfj.org/news/journalism-pandemic-threats-media-freedom-safetyduring-covid-19

12. Erdősi, Rebeka; Gosztonyi, Gergely; Gyetván, Dorina; Kiss, Nóra; Mező, Emese; Sziládi, Péter; Tatár, Attila, 2020: Memorial for Respondent 2018/2019. Ad perpetuam rei memoriam III., p. 68.

13. European Digital Rights Organization, EDRI (2020, September 14): EDRi with 25 organisations urge Parliament to protect journalists, doctors, lawyers, social services. https://edri.org/our-work/edri-with-25-organisations-urge-parliamentto-protect-journalists-doctors-lawyers-social-services/ 
14. European Western Balkans, EWB (2020, April 2): Serbian journalist arrested for reporting on difficult working conditions of medical staff in Covid-19 pandemic. https://europeanwesternbalkans.com/2020/04/02/serbian-journalist-arrested-forreporting-on-difficult-working-conditions-of-medical-staff-in-covid-19pandemic/

15. Fabók, Bálint; Pethö, András; Szabó, András, 2016: Inside the killing of Népszabadság, Hungary's biggest opposition paper.https://www.direkt36.hu/en/ilyen-volt-a-nepszabadsag-halala-belulrol/

16. Freedom House report, FH 2020. Hungary. https://freedomhouse.org/country/hungary/freedom-world/2020

17. Hungarian Constitutional Court, HCC, 2020: The Government Decree classifying as of national strategic importance the intention to ectend the Central European Press and Media Foundation is not in conflict with the Fundamental Law, https://tinyurl.com/y2rrgwam

18. Index on censorship (2020a, Mar 18): Disease control?, Mapping attacks on media freedom during the coronavirus crisis. https://www.indexoncensorship.org/disease-control/

19. Index on censorship (2020b, Mar 18): 150 attacks on media freedom reported in 50 days. https://www.indexoncensorship.org/2020/05/150-attacks-on-mediafreedom-reported-in-50-days/

20. International Press Institute (2020a, Mar 23): Hungary seeks power to jail journalists for 'false' Covid-19 coverage, https://ipi.media/hungary-seeks-powerto-jail-journalists-for-false-covid-19-coverage/

21. International Press Institute (2020b, Mar 30): Hungary: Press freedom threatened as Orbán handed new powers, https://ipi.media/hungary-press-freedomthreatened-as-orban-handed-new-powers/

22. International Press Institute (2020c, June 4): Access to information and the safety of journalists in times of crisis. https://ipi.media/access-to-information-and-thesafety-of-journalists-in-times-of-crisis-right-on-june-4-2020/

23. Janjić, Dragan (2020, April 17): Željko Bodrožić: the state of emergency smothers the Serbian media. Osservatorio Balcani e Caucaso Transeuropa: https://www.balcanicaucaso.org/eng/Areas/Serbia/Zeljko-Bodrozic-the-state-ofemergency-smothers-the-Serbian-media-201029

24. Kaszás, Fanni, 2020: National Media and Info-communications Authority Revokes Frequency License of Klubrádió, https://hungarytoday.hu/national-media-andinfo-communications-authority-revoke-frequency-license-of-klubradio/ 
25. Kaye, David, 2020: Disease pandemics and the freedom of opinion and expression. Report of the Special Rapporteur on the promotion and protection of the right to freedom of opinion and expression. Human Rights Council, Fortyfourth session, 15 June - 3 July 2020, A/HRC/44/49

26. Koltay, András, 2013: Hungarian Media Law. Wolters Kluwer Kft.

27. Kurir (2020a, April 7): Novinarka Ana Lalic svesno lagala: Pogazila kodeks da bi unela strah među ljude, Kurir.rs:

https://www.kurir.rs/vesti/drustvo/3442459/novinarka-ana-lalic-svesno-lagalapogazila-kodeks-da-bi-unela-strah-medju-ljude

28. Kurir (2020b, April 7): Struka osudila neodgovorno izveštavanje, Kurir.rs: https://www.kurir.rs/vesti/drustvo/3442985/struka-osudila-neodgovornoizvestavanje-ane-lalic-dr-kisic-takve-price-nas-ometaju-dok-spasavamo-zivote

29. Kurir (2020c, April 2): Kurir saznaje: Novinarki Lalickoja je objavljivala netačne informacije o kcv vraćeni svi elektonski uređaji, Kurir.rs: https://www.kurir.rs/vesti/drustvo/3439817/kurir-saznaje-novinarki-lalic-koja-jeobjavljivala-netacne-informacije-o-kcv-vraceni-svi-elektronski-uredjaji

30. Marktler, Tanja, 2006: The Power of the Copenhagen Criteria. Croatian Yearbook of European Law and Policy 2(2)

31. McGonagle, Tarlach, 2013: How to address current threats to journalism?: The role of the Council of Europe in protecting journalists and other media actors. https://rm.coe.int/1680484e67

32. McGonagle, Tarlach; Voorhoof, Dirk, 2013: Freedom of Expression, the Media and Journalists: Case-law of the European Court of Human Rights, European Audiovisual Observatory, Strasbourg

33. McGonagle, Tarlach; et al., 2020: Safety of journalists and the fighting of corruption in the EU, Policy Department for Citizens' Rights and Constitutional Affairs, European Parliament

34. Media Freedom Rapid Response, MFRR, 2020: A four-month snapshot (March June 2020). https://www.mfrr.eu/wp-content/uploads/2020/07/MFRRMonitoring-Report-FINAL.pdf

35. Mérték Media Monitor, 2012:Forced Maneuver: Proposals and Expectations toward the Amendment of the Media Act

36. Milovanović, Tanja (2020, April 15): Platili oglas na Guglu s pozivom na linč Ane Lalic, Nova.rs: https://nova.rs/vesti/hronika/nasa-novinarka-ana-lalic-izlozenaotvorenom-pozivu-na-linc/

37. Mong, Atilla (2020, April 29):Serbian reporter Ana Lalicon her arrest and detention over Covid-19 report. Committee to Protect Journalists: https://cpj.org/2020/04/serbian-reporter-ana-lalic-on-her-arrest-and-deten/.

38. MTI (2003, May 26): Orbán ismét felvetette a két közszolgálati csatorna tervét. https://index.hu/belfold/orban0526/ 
39. Navratil, Szonja, 2015: A Mérték Médiaelemzö Mühely sajtószabadság-indexe, p. 177., quoted by Polyák, Gábor, 2015: The Hungarian Media System. Stopping Short or Re-Transformation? Südosteuropa 63, no. 2, p. 312.

40. Nikolic, Ivana; Jeremic; Ivana (2020, April 10): 'Vox Populi': How Serbian Tabloids and Twitter Bots Joined Forces, Belgrade, BIRN:

https://balkaninsight.com/2020/04/10/vox-populi-how-serbian-tabloids-andtwitter-bots-joined-forces/

41. Plattner, Marc F.: Illiberal Democracy and the Struggle on the Right. Journal of Democracy, vol. 30, no. 1, 2019, pp. 5-19.

42. Polyák, Gábor, 2015: The Hungarian Media System. Stopping Short or ReTransformation? Südosteuropa 63, no. 2, p. 284.

43. Reporters without Borders, RSF (2020c, Apris 8): Repressive laws, prosecutions, attacks... Europe fails to shield its journalists against the abuse of the Covid-19 crisis, Ecoi.net: https://www.ecoi.net/en/document/2027798.html

44. Reporters without Borders, RSF 2020a. Hungary. https://rsf.org/en/hungary

45. Reporters without Borders, RSF 2020b. Serbia. https://rsf.org/en/hungary

46. SHARE Foundation monitoring database, 2020: http://monitoring.labs.rs/

47. Smajić, Mehmed (2020, May 5): Ana Laličrrtva "demokratije" u Srbiji, Deutche Welle: https://www.dw.com/bs/ana-lali\%C4\%87-\%C5\%BErtva-demokratije-usrbiji/a-53330086

48. Srdić, Mladen, 2012: Defamation in Court Practice. In: Halilović, Mehmed; Džihana, Amer: Media law in Bosnia and Herzegovina, Internews in Bosnia and Herzegovina, Sarajevo, 2012

49. The Editorial Board, 2018: No News Is Bad News for Hungary. The autocrat Viktor Orban has taken control of much of the country's media. New York Times, 3 December 2018, https://www.nytimes.com/2018/12/03/opinion/hungary-orbanmedia-suppression.html

50. Voorhoof, Dirk (2014, February 14): The Right to Freedom of Expression and Information under the European Human Rights System: Towards a more Transparent Democratic Society: https://tinyurl.com/y5rn3lm3

51. Wiseman, Jamie (2020, May 18): Crisis point: Covid-19 intensifies challenge for independent media in Hungary, https://ipi.media/crisis-point-covid-19intensifies-challenge-for-independent-media-in-hungary/

52. 2017/2131(INL): European Parliament resolution of 12 September 2018 on a proposal calling on the Council to determine, pursuant to Article 7(1) of the Treaty on European Union, the existence of a clear risk of a serious breach by Hungary of the values on which the Union is founded 